https://doi.org/10.15407/ujpe65.1.82

I.V. KORSUN

Volodymyr Hnatiuk National Pedagogical University of Ternopil

(2, M. Kryvonosa Str., Ternopil 46027, Ukraine; e-mail: korsun_igor@i.ua)

\title{
CONTRIBUTION OF UKRAINIAN SCIENTISTS TO THE DEVELOPMENT OF ELECTRODYNAMICS
}

\section{Introduction}

Ukraine is a country with a high level of science development. One of effective ways to raise the information awareness about Ukraine throughout the world consists in spreading the knowledge about Ukrainian scientists. Therefore, it is important that, nowadays, we should demonstrate the achievements of Ukrainian scientists made by them in various historical periods to the world community.

For instance, in 1941, Academician of the Academy of Sciences of the Ukrainian SSR (AS UkrSSR) V.E. Lashkaryov (1903-1974) for the first time experimentally proved the existence of $p-n$ junction $[1,2]$. This discovery had been done several years before the relevant works of US scientists J. Bardeen [3], W. Brattain [4], and W. Shockley [5] were published. V.E. Lashkaryov explained the injection mechanism, which is the basis of the functioning of semiconductor diodes and transistors. During World War II, the Ukrainian scientist designed a copper-

(C) I.V. KORSUN, 2020

82 oxide diode, which was used in field radio stations. In the early 1950s, the production of point-contact transistors was organized under the supervision of V.E. Lashkaryov at the Institute of Physics (IP) of the AS UkrSSR. At present, the contribution of the Ukrainian scientist to the formation of semiconductor physics has been thoroughly analyzed in a number of papers [6-8]. Now, the work by V.E. Lashkaryov has been translated into English and published in the Ukrainian Journal of Physics [9]. But only the American scientists were awarded the Nobel Prize in Physics in 1956 "for their researches on semiconductors and their discovery of the transistor effect".

The importance of every scientific work is determined by its significance for the development of the corresponding field of science. Proceeding from this statement, let us analyze the contribution of Ukrainian scientists to the development of electrodynamics. Our final aim is to prove the importance of scientific achievements made by Ukrainian scientists to the development of this physical domain.

ISSN 2071-0194. Ukr. J. Phys. 2020. Vol. 65, No. 1 


\section{Electric Current Laws}

In 1864, the future Professor of the St. Volodymyr University (Kyiv) M.P. Avenarius (1835-1895) defended his master thesis "On thermoelectricity" [10], where he formulated the law of the temperature dependence of a thermoelectromotive force. In 1866, the scientist was awarded a doctorate for his work "On electric differences of metals at various temperatures".

M.P. Avenarius [11,12] proceeded from the assumption that the contact potential difference between metals, $e$, depends on the temperature $t$ according to the parabolic law

$e=a+b t+c t^{2}$,

where $a, b$, and $c$ are certain coefficients. Supposing that the thermoelectromotive force is only determined by the contact potential differences at two junctions having the temperatures $t_{1}$ and $t_{2}$, the scientist obtained the formula

$e=b\left(t_{1}-t_{2}\right)+c\left(t_{1}^{2}-t_{2}^{2}\right)$.

If we take the temperature $t_{2}=0{ }^{\circ} \mathrm{C}$, law (2) can be rewritten in the form

$e=b t_{1}+c t_{1}^{2}$.

Formula (3) describes the temperature dependence of the thermoelectromotive force with a rather high accuracy for many thermoelectric "pairs". However, in some foreign textbooks, the Avenarius law is unfoundedly called the Theta formula (see, e.g., works [13, p. 47] and [14, p. 590]). Nowadays, the Avenarius law is used to calibrate thermocouples $[15$, p. 7]. Thus, the Ukrainian scientist M.P. Avenarius proved that the contact potential difference is a function of the temperature. He also determined data required to calculate the numerical values of the potential difference for plenty pairs of metals.

In his master thesis "On the significance of nonconductors in electrostatics" [16], the future Rector of the Imperial Novorossiisk University (Odessa) F.N. Shvedov (1840-1905) studied the phenomenon of heating in the electric spark. In his doctoral thesis "On the conversion laws of electricity into heat" [17], the scientist experimentally studied the laws required to calculate the amount of heat that is released in the course of an electric discharge. After defending his doctoral thesis, F.N. Shvedov began lecturing at the Department of Physics and Physical Geography of the Imperial Novorossiisk University. The scientist was appointed the head of the physical cabinet,

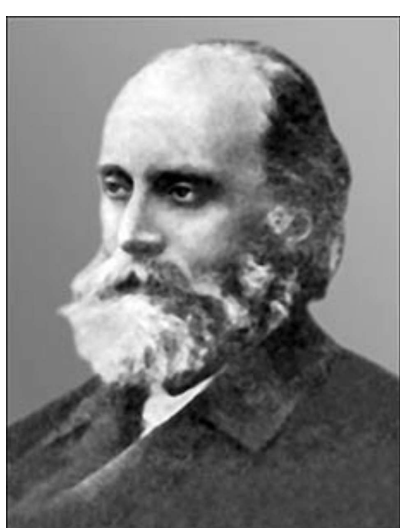

M.P. AVENARIUS

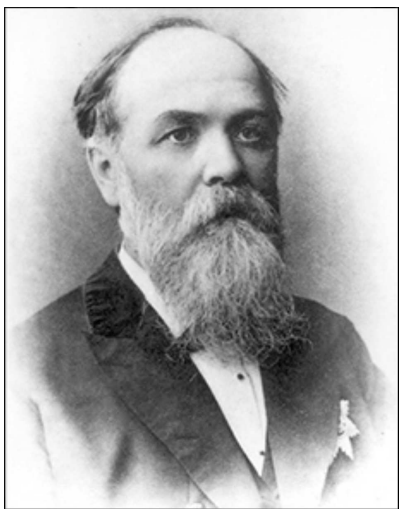

F.N. SHVEDOV

which he expanded and completely reequipped [18, p. 40]. F.N. Shvedov emphasized that physics could not be developed without experiments. Therefore, he initiated laboratory works and accompanied his lectures with the demonstration of experiments carried out with the use of the factory- and self-made equipments. His lectures were quite popular among the students owing to the simplicity and originality of their presentation. The scientist was a well-known interpreter of science to the public and often made popular scientific lectures [19]. F.N. Shvedov believed that science played an important role in the development of the society, and, therefore, he opposed to the formal teaching of physics at the secondary school. The scientist was an author of a manual on the methodology of teaching physics [20].

In 1885, the Ukrainian scientist M.M. Benardos (1842-1905) obtained a patent in a number of European countries (France, Belgium, England, Sweden, and Germany) for his own method of electric arc weld- 


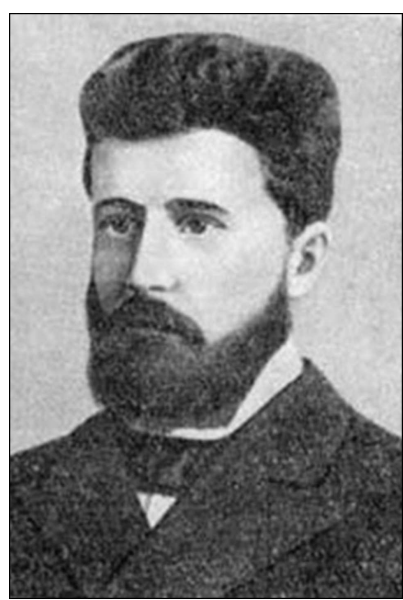

M.M. BENARDOS

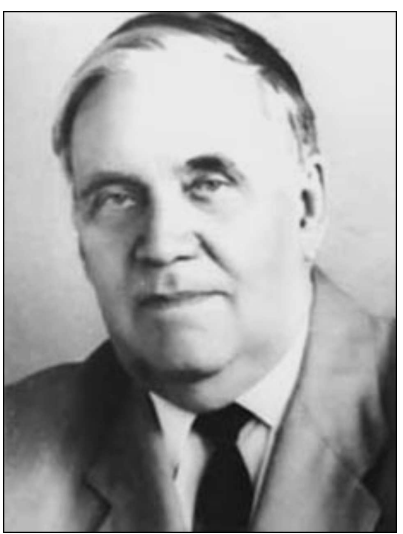

K.K. KHRENOV

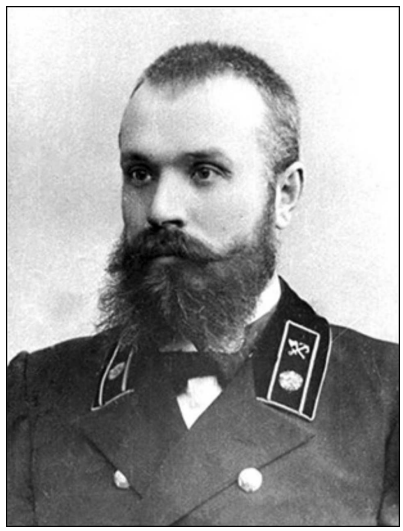

E.O. PATON

ing of metals. An electric arc appeared between a carbon electrode and a metal object to be welded. The inventor proposed the methods of resistance-spot and resistance-seam welding of metals. The Benardos method could also be used to cut metals. The scientist invented some systems of automatic welding devices with coal and metal electrodes. To accelerate the introduction of electric welding into the industry, M.M. Benardos created a special type of batteries to feeding the electric arc. He also marked a possibility to apply the electric welding underwater [21, p. 45].

In 1932, K.K. Khrenov (1894-1984) experimentally demonstrated, for the first time in the world, a possibility for a welding arc to steadily burn in water, which allowed the scientist to develop methods of underwater electric welding and cutting of metals [22]. The welding of metal under water was performed in the same ways as in air. The quality of the underwater welding was rather high, being practically not worse that the quality of welding in air.

During World War II, the method of underwater electric welding of metals developed by K.K. Khrenov was widely applied to repair the damages of ships and submarines. It allowed their battle capability to be restored in a short time because the ships could be repaired at the sea. The scientist worked at the Institute of Electric Welding of the AS UkrSSR (in 1945-1948), the Institute of Building Mechanics of the AS UkrSSR (in 1948-1952), the Institute of Electrical Engineering of the AS UkrSSR (from 1952), and the E.O. Paton Institute of Electric Welding of the AS UkrSSR (from 1963). He was also the Professor of the Kyiv Polytechnic Institute (in 1947-1958).

In 1940, scientists of the Institute of Electric Welding of the AS UkrSSR headed by E.O. Paton (18701953) developed a high-rate method of welding under a flux [23]. The method of Ukrainian scientists allowed the manual welding to be abandoned and the mechanized one to be engaged. The automatic flux welding was applied to organize the mechanized serial production of armored tank corps. The pre- and post-war periods in the activity of the Institute, which was named after E.O. Paton in 1945, can be considered as the formation of a new scientific school (V.V. Shevernytskyi, O.A. Kazimirov, G.V. Raevskyi, A.M. Makara, B.E. Paton, B.I. Medovar, D.M. Rabkin, I.I. Frumin). E.O. Paton achieved the significant progress in constructing bridges and in the metal welding. The world's first fully welded bridge across the Dnieper river in Kyiv, which was built under his direction, was named after him.

ISSN 2071-0194. Ukr. J. Phys. 2020. Vol. 65, No. 1 
In the works by P.G. Borzyak (1903-2000) and his collaborators, which were carried out at the IP of the AS UkrSSR, the physical nature of various photocathodes was studied. The Corresponding Members of the AS UkrSSR P.G. Borzyak and N.D. Morgulis together with B.I. Dyatlovytska for the first time obtained such parameters of photocathodes as their optical constants and the depth of photoelectron emission. P.G. Borzyak performed thorough studies of the photovoltaic effect at low temperatures [24] and obtained a maximum value of $0.68 \mathrm{~V}$ for the photoelectromotive force in experiments with copper-oxidebased photocells.

The scientist discovered the exciton absorption of light in stibium-cesium and tin-cesium semiconductor films, as well as the photoelectron emission associated with this phenomenon. He performed considerable researches of the electron emission in semiconductors. He was the first who obtained the emission of hot electrons from cold crystals and films of some semiconductors. He also developed a new type of highly sensitive electron-emission indicators of infrared radiation, the so-called photo-field cathodes. In 1963, P.G. Borzyak, O.G. Sarbey, and R.D. Fedorovych discovered a new phenomenon of the electron emission in thin dispersed metal films, which was registered at the State Committee on Discoveries and Inventions at the Council of Ministers of the USSR as a discovery (diploma No. 31 from December 14, 1963).

\section{Magnetism}

When studying the Kursk magnetic anomaly, the Ukrainian inventor M.D. Pilchikov (1857-1908) correctly pointed out that magnetic anomalies are associated with iron-ore deposits. The results of those researches formed a basis for writing a master thesis entitled "Materials on the isuue of local anomalies in terrestrial magnetism" [25], which he defended at the St.-Petersburg University in 1887. After the confirmation of his master degree in physics and physical geography, M.D. Pilchikov was sent to France for two years to a scientific internship. In France, he studied the phenomenon of electrolysis [26, 27].

D.A. Rozhanskyi (1882-1936) is the founder of the magnetism theory in Ukraine [28, p. 135]. In 19111921, the scientist lectured at the Kharkiv University (from 1914, he was Professor and Head of the Department of Physics and Physical Geography). When

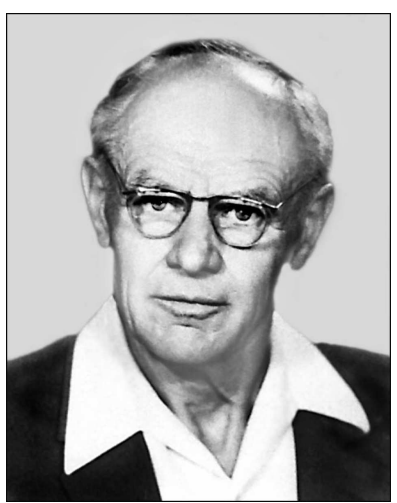

P.G. BORZYAK

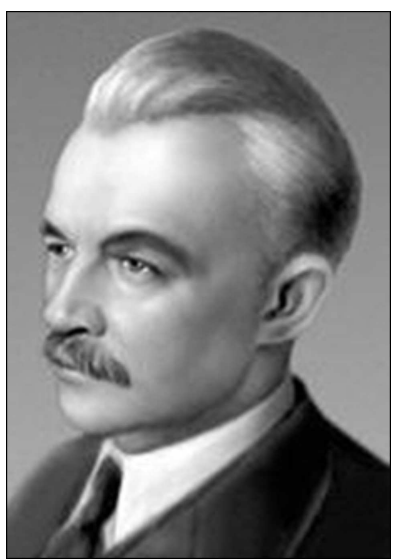

D.A. ROZHANSKYI

working at the Kharkiv University, D.A. Rozhanskyi wrote one of his fundamental works [29], where he expounded the physical fundamentals of radio engineering at a high scientific level.

In 1911, D.A. Rozhanskyi invited D.S. Shteinberg (1874-1934) to the Kharkiv University for the development of scientific research works at the University. When working at the Kharkiv University, D.S. Shteinberg studied changes in the electrical conductivity of molybdenum crystals under the action of light. He created a department of magnetic measurements at the University. The scientist performed a number of important works dealing with the magnetic properties of ferromagnetic powders [30,31]. In particular, the coercive force was proved to increase with a decrease in the size of separate grains.

At the Physics Laboratory of the Kharkiv University, D.S. Shteinberg constructed, for the first time in the Russian Empire, a pocket magnetometer 


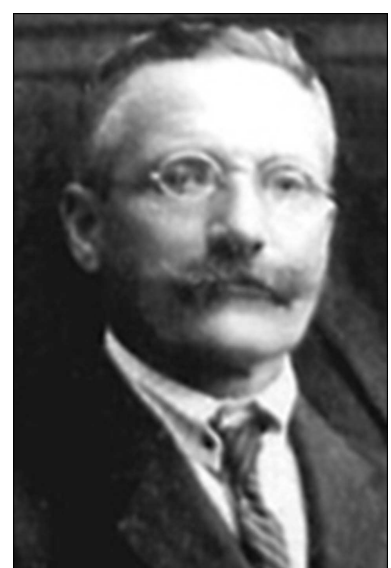

D.S. SHTEINBERG

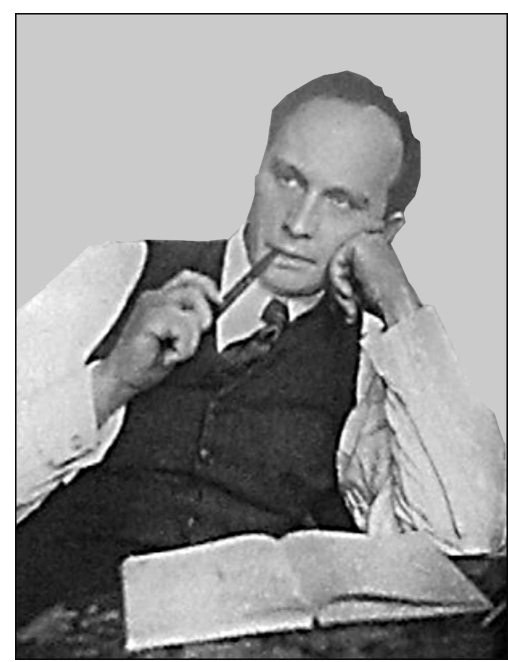

L.V. SHUBNIKOV

[32]. The magnetometer was tested near the town of Zmiiv (the Kharkiv province). The results obtained by Prof. Shteinberg and his colleagues were widely used by other researchers. In 1931, the magnetic laboratory first in Ukraine headed by D.S. Shteinberg was established at the Ukrainian Physico-Technical Institute (UPTI).

The Ukrainian physicist L.V. Shubnikov (19011937) worked at the Leiden Cryogenic Laboratory (Netherlands) in 1926-1930. The scientist managed to obtain extremely pure bismuth single crystals for carrying out accurate measurements of electrical conductivity at low temperatures in the external magnetic field. At that time, this problem was studied exclusively making use of bismuth crystalline specimens fabricated from large crystals by means of their mechanical treatment. The specimens were often damaged during their treatment, and the results obtained were not consistent with one another. By improving P.L. Kapitsa's method of cultivating bismuth single crystals from a melt, L.V. Shubnikov and the Dutch physicist W.J. de Haas managed to produce bismuth crystals with a low impurity concentration. In 1930, the scientists discovered oscillations in the magnetoresistance of bismuth films at low temperatures $[33,34]$. This was the first quantummechanical effect discovered in solids. Later on, it was called the Shubnikov-de Haas effect. The discovery of the Ukrainian scientist found practical applications, in particular, when studying the energy spectrum in metals and semiconductors [35]. When working at the UPTI, L.V. Shubnikov performed a thorough study of the magnetic properties of superconductors. The scientist experimentally discovered the antiferromagnetism phenomenon [36, p. 323]. However, his life and creative plans were interrupted by an unjust arrest and execution by shooting in 1937. The last works by L.V. Shubnikov were published in 1938-1939 without indicating his name. In his Nobel lecture on physics, A.A. Abrikosov marked that the results obtained by L.V. Shubnikov served as a source for his (Abrikosov) inspiration [37, p. 1238].

In 1932, the theoretical department of the UPTI was headed by L.D. Landau (1908-1968). When working in Kharkiv, the scientist performed fundamental theoretical works in magnetism. In 1933, when studying the dependence of the magnetic susceptibility in a definite class of substances on the magnetic field magnitude at low temperatures, L.D. Landau for the first time introduced the concept of antiferromagnetism as a special phase of the magnet, which differs from a paramagnet by its symmetry [38]. It is known that L. Neél predicted the existence of antiferromagnetism in his work [39, p. 179] carried out before Landau's research. But L.D. Landau did not know about the work of the French scientist, and L. Neél did not mean that the issue concerned the existence of a separate state of matter. An idea aboutthe structure of ferromagnets, which consists of elementary regions that are spontaneously magnetized in different directions, was put forward by P. Weiss as early as in 1907. However, there was no approach to the quantitative theory of magnetic domains. It was L.D. Landau and E.M. Lifshits (1915-1985) who showed in 1937 that this theory should be based on 
thermodynamic speculations [40]. The macroscopic equation of motion for the domain magnetization vector was derived, and, making use of of this equation, the scientists predicted the phenomenon of ferromagnetic resonance.

The properties of ferrites with a cubic structure and thin magnetic films were studied at the General Physics Department of the Kharkiv University. The department was headed by A.S. Milner. Those researches made it possible to develop materials that are used in high- and super-high frequency techniques. In the mid 1950s, Ye.S. Borovyk (1915-1966) organized a specialty "Physics of Magnetic Phenomena" at the General Physics Department [41, p. 76]. Problems associated with the magnetization, magnetostriction, magnetic anisotropy, exchange interaction in ferrite, and ferromagnetic and nuclear magnetic resonances were investigated. When working on his doctoral dissertation entitled "Electromagnetic phenomena and properties of conduction electrons in metals", Ye.S. Borovyk studied the Hall effect and the magnetoresistance of metals in strong magnetic fields. By analyzing the electrical conductivity in metals at high current densities, the scientist experimentally determined deviations from Ohm's law [42]. Ye.S. Borovyk together with A.S. Milner published a course of lectures on magnetism [43]. Later on, this textbook was extended and republished [44].

Considerable researches in the theoretical physics of magnetic phenomena were carried out by Academician of the National Academy of Scienses of Ukraine (NASU) V.G. Bar'yakhtar. The scientist was the first who described the thermodynamic properties of antiferromagnets in strong magnetic fields. He studied the character of the magnetic moment relaxation phenomena in ferromagnets and antiferromagnets, as well as the high-frequency properties of magnets. In particular, he developed a theory describing the shape of the ferromagnetic resonance line and explained the nonlinear dependence of the temperature of the superconducting transition under pressure on a change in the topological structure of the Fermi surface of a superconducting metal [45, pp. 16 and 17].

\section{Electrical Engineering}

The Ukrainian engineer F.A. Pirotskyi (1845-1898) was the inventor of the world's first tram with an electric traction [46]. A possibility of transmitting electricity over long distances $(60 \mathrm{~km})$ was demonstrated

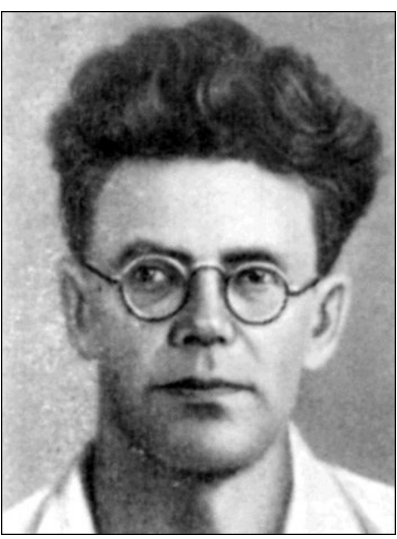

Ye.S. BOROVYK

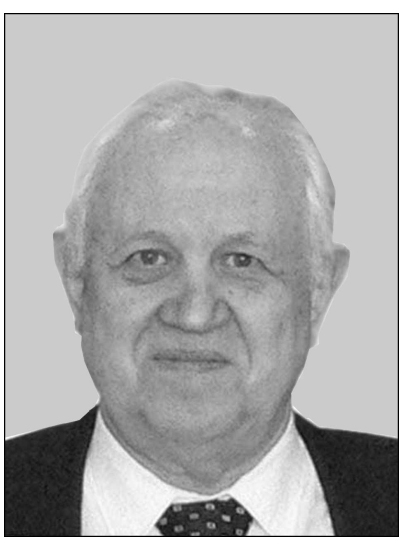

V.G. BAR'YAKHTAR

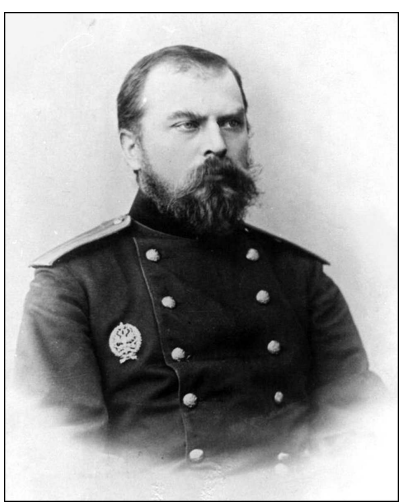

F.A. PIROTSKYI

by the French engineer M. Deprez in 1882. However, as early as in 1874, Pirotskyi carried out a series of experiments that demonstrated a possibility of transmitting electricity over a distance of $50 \mathrm{~m}$. 


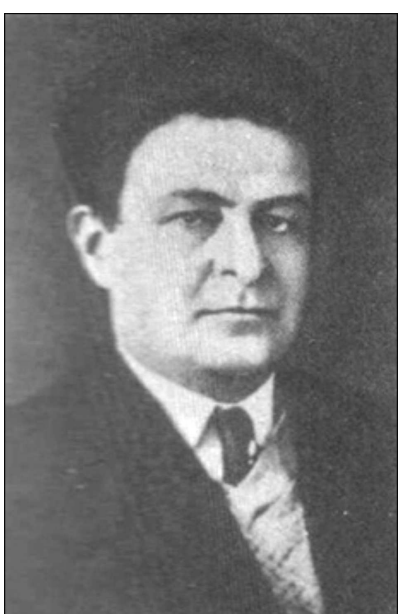

A.O. SLUTSKIN

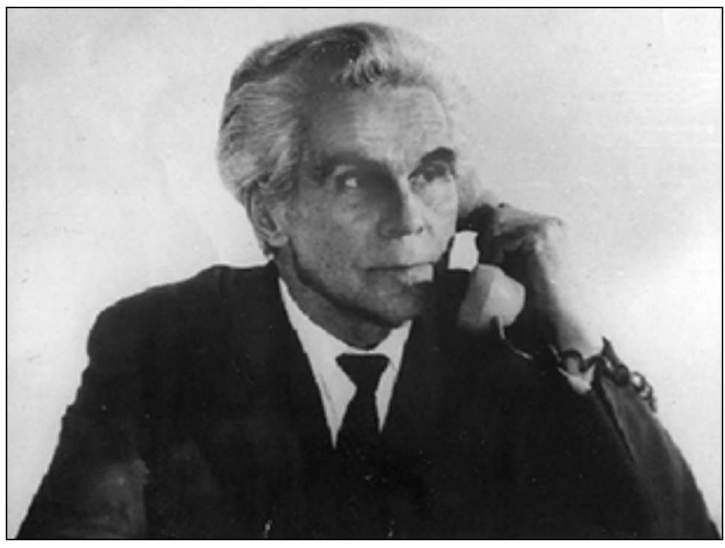

O.Ya. USIKOV

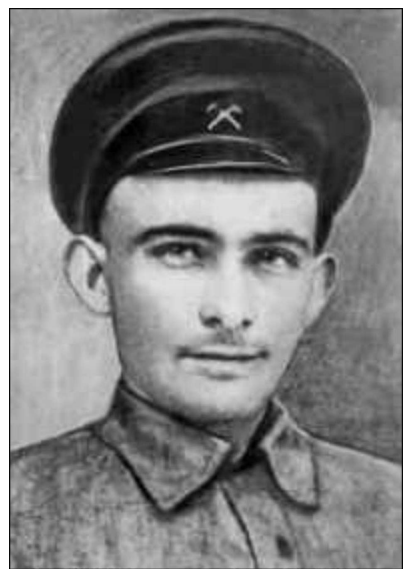

B.P. GRABOVSKYI
F.A. Pirotskyi came to an idea of using the rails of existing railways to transmit electricity. In 1880, he demonstrated the transmission of electric current through the rails of the railway in St. Petersburg. With the help of direct current at a voltage of $100 \mathrm{~V}$, the scientist set in motion a tram-car installed on the rails. The car of the first electric tram could move at a velocity of $10-12 \mathrm{~km} / \mathrm{h}$.

In the Russian Empire, Pirotskyi's invention underwent protests from entrepreneurs who invested into the development of trams with the horse traction. But Pirotskyi's works invoked interest in the scientific world. The world's first electric tram line was opened in Berlin in 1881. The first electric tram line in the Russian Empire was opened only in 1892 in Kyiv.

The Ukrainian scientist I.P. Pulyui (1845-1918) worked on improving the design of incandescent lamps. He created his own technology of filament fabrication. Improved filaments made it possible to prolong the lamp life cycle and increase the lamp power. For this invention, Pulyui obtained a patent. In 1883, the scientist was invited to the consultant position at the arms factory in the Austrian city of Steyr, where he organized the fabrication of incandescent lamps of his own design. Pulyui's lamps were demonstrated at the International Electrotechnical Exhibition in Steyr in 1884. Ivan Pulyui took part in the building of the first in Europe ac power plant (in Prague).

\section{Radio Engineering}

The Ukrainian scientist M.D. Pilchikov for the first time in the world realized a distant radio control of objects. On March 25, 1898, he gave a public lecture at the Exchange Hall in Odessa, where he demonstrated the operation of a clock controlled by radio waves, as well as the operation of a radio semaphore and a radio beacon [47, p. 131]. In his lecture, the scientist also reported that he had developed a device providing a transmission of radio telegrams, at which they could not be received by anyone but the addressee. Note that Nikola Tesla demonstrated the operation of a radio-controlled boat for the first time only in September 1898. During World War II, the concept of radio control invented by M. Pilchikov found its practical implementation in the demolition of the German headquarters of General von Braun in occupied Kharkiv (1943). 
Professors of the UPTI A.O. Slutskin (1891-1950) and D.S. Shteinberg studied new methods for generating short radio waves. In 1924, for the first time in the world, the scientists experimentally created an ultra-high frequency magnetron generator [48]. At that time, it was the most efficient ultra-high frequency generator. In the course of its further development, it became one of the basic components of a modern radar equipment.

Experimental and theoretical studies of the physical processes associated with the wave generation in magnetrons were carried out at the UPTI, at the Department of Electromagnetic Oscillations headed by the Academician of the AS UkrSSR A.O. Slutskin [49, pp. 28 and 29]. The works of this department were mainly aimed at studying the physical processes occurring when powerful oscillations in the decimeter wavelength range were generated with the help of magnetrons with the cutting anode; in particular, these were the so-called "dynatron" oscillations. On the basis of those researches, the first in the former Soviet Union model of the $64-\mathrm{cm}$ radar was developed at the UPTI.

Further researches in this area obtained an impetus in 1955, when the Institute of Radiophysics and Electronics (IRE) of the AS UkrSSR was organized on the basis of the radiophysical departments of the UPTI. Here, under the leadership of O.Ya. Usikov (1904-1995), a series of works were carried out, in which the problems of the influence of such properties and parameters of the environment as Earth's curvature, changes in the density and composition of air with the altitude, the surface relief, and oscillations of plants on the propagation of radio waves was studied.

The researches of the radio wave propagation over the interface between two media brought to the discovery of radio oceanography, a domain of oceanography in which the structure and parameters of the sea surface are analyzed by means of radio waves emitted, scattered, and absorbed by this surface. Highfrequency wave processes in metals and semiconductors at temperatures close to $0 \mathrm{~K}$ were also studied at the IRE of the AS UkrSSR. A group of the IRE scientists headed by the Corresponding Member of the AS UkrSSR S.Ya. Broude (1911-2003) developed a special radio astronomical equipment that made it possible to analyze the radio emission of discrete cosmic sources, the Sun, and the galactic background at decameter and shorter radio waves. The scientists created a catalog of radio stars and plotted the maps of the cosmic radio emission. They also studied the structure of some radio astronomical objects. A number of important researches were carried out in order to elucidate whether andalusite crystals with iron impurities could be used as an active substance in quantum paramagnetic amplifiers.

The Ukrainian inventor B.P. Grabovskyi (19011966) for the first time in the world created an electronic system for the wireless transmission of moving images over the distance and practically performed a broadcasting according to this scheme. As early as in 1921-1923, the scientist developed, constructed, and manufactured an electron transmission tube. Later, he worked on improving the television equipment. In 1928, B.P. Grabovskyi together with M.G. Piskunov and V.I. Popov obtained a patent for electronic television [50].

\section{Conclusions}

Ukrainian scientists are authors of a number of physical theories. In particular, Professor of the St. Volodymyr University L.Y. Kordysh developed a theory of electrical conductivity, in which the electric current was considered as a set of sequential ionization and reduction processes of conductor atoms. The discovery of the Shubnikov-de Haas effect resulted in the development of the physics of the magneticfield-induced oscillations in both kinetic and thermodynamic parameters of metals, alloys, and degenerate semiconductors with various symmetries, compositions, sizes, and Fermi surface shapes. The theory of the domain structure in the ferromagnet was created in the works by L.D. Landau and E.M. Lifshits (UPTI). N.D. Morgulis (IP of the AS UkrSSR) developed the theory of electron field emission from semiconductors, discovered a growth of the secondary emission from oxide cathodes with the temperature, and together with P.M. Marchuk discovered the thermal emission method for converting the electric energy. V.G. Bar'yakhtar, O.I. Akhiezer, and S.V. Peletminskyi discovered the magnetoacoustic resonance phenomenon. V.E. Lashkaryov (IP of the AS UkrSSR) was an author of the theory of photoelectromotive force in semiconductors; he studied the mechanisms of a photoelectromotive force in cuprous oxide and recombination in cadmium selenide, showed that the nonphotovoltaic electromo- 
tive force is determined by the diffusion of minor charge carriers, and together with V.O. Romanov discovered the bulk-gradient photoelectromotive force in germanium. The first director of the Institute for Theoretical Physics of the AS UkrSSR M.M. Bogolyubov created a microscopic theory of superconductivity. Ye.S. Borovik (UPTI) thoroughly studied the magnetic properties of hexagonal ferrites; he obtained ferrites with a high energy of anisotropy, a large coercive force, and a large residual induction; he was the first who obtained mixed ferrites with zero energy of anisotropy and a high initial susceptibility; he studied the behavior of electrons in metals in strong electric and magnetic fields, which enabled the development of a new method for the simultaneous measurement of the Hall effect and the magnetoresistance; he also experimentally discovered a deviation from Ohm's law in bismuth at high current densities. Owing to the works by V.G. Bar'yakhtar, O.O. Galkin, S.M. Kovner, and Ye.P. Stefanovskyi (Donetsk Institute of Physics and Technology of the AS UkrSSR), the intermediate state in antiferromagnets was discovered and studied both experimentally and theoretically. Researches of a high conductivity in graphene, which were carried out by Ukrainian scientists at the M.M. Bogolyubov Institute for Theoretical Physics and the G.V. Kurdyumov Institute of Metal Physics formed a basis for the discovery of this new material.

Some of inventions were made for the first in the world by Ukrainian scientists. The invention of an electric tram belongs to F.A. Pirotskyi, the direct broadcasting of moving images to B.P. Grabovskyi, and the distant radio control of objects to M.D. Pilchikov. M.P. Avenarius developed a method for supplying Yablochkov candles with the alternating electric current; for this method, he was awarded the silver medal of electrical exhibition in Paris. The method of arc welding of metals proposed by M.M. Benardos is used in many technological operations throughout the world: welding, cutting, drilling, melting. K.K. Khrenov developed a method for the underwater electric arc welding and cutting of metals. Researches of E.O. Paton were continued by Ukrainian scientists under the leadership of his son B.E. Paton at the E.O. Paton Institute of Electric Welding, where new developments in this field of science were made. For the first time in the world, Ukrainian scientists developed a special equipment for the welding in outer space, and this equipment was successfully used at welding, cutting, soldering, and coating operations. The works of UPTI employees (A.O. Slutskin, O.Ya. Usikov, S.Ya. Braude, I.D. Truten', I.M. Vygdorchyk, I.M. Sorkin) resulted in the creation of the first in the USSR radar station in the decimeter range, which could determine three coordinates of the airplane and was successfully used for the defense of Moscow in the course of World War II. The founder of the scientific school of semiconductor materials science in Ukraine K.D. Tovstyuk developed new types of batteries and capacitors, which differed from chemical ones in that the entire volume rather than only the surface became charged. Now, the scientists from the M.M. Bogolyubov Institute for Theoretical Physics work in the field of molecular electronics, with the aim of miniaturizing its experimental base.

Ukrainian scientists were engaged not only in scientific and lecturing activities, but also in the popularization of science, reformation of the education system, and social activity. It is known that both the university and public lectures of M.P. Avenarius and F.N. Shvedov attracted high interest. M.D. Pilchikov delivered public lectures in Kharkiv, Odessa, Kherson, Mykolaiv, and Chisinau. This scientist created a magnetic-meteorological department and a meteorological station at the Kharkiv University and a physical laboratory for measurements at the Novorossiisk University. At his own expense, M.D. Pilchikov built the first radio station in Ukraine. He favored the publication of books in Ukrainian. L.V. Shubnikov founded the first in the USSR cryogenic laboratory at the UPTI. V.E. Lashkaryov was the Editor-in-Chief of the Ukrainian Journal of Physics. V.G. Bar'yakhtar actively participated in the works on the elimination of the consequences of the Chornobyl disaster, being a member of relevant councils and groups, and the Chairman of the Commission on Chornobyl problems at the Academy of Sciences of Ukraine.

1. V.E. Lashkaryov. Investigations of a barrier layer by the thermoprobe method. Izv. Akad Nauk SSSR Ser. Fiz. 5, 442 (1941) (in Russian).

2. V.E. Lashkaryov, K.M. Kosonogova. Influence of impurities on photovoltaic effect in cuprous oxide. Izv. Akad Nauk SSSR Ser. Fiz. 5, 478 (1941) (in Russian).

3. J. Bardeen. Surface states and rectification at a metalsemiconductor contact. Phys. Rev. 71, 717 (1947).

ISSN 2071-0194. Ukr. J. Phys. 2020. Vol. 65, No. 1 
4. W.H. Brattain. Bell Labs Notebook No. 18194 (AT\&TArchives, 1947).

5 . W. Shockley. The theory of $p-n$ junctions in semiconductors and $p-n$ junction transistors. Bell Syst. Tech. J. 28, 435 (1949).

6. B. Malynovskyi. Known and unknown in the history of information technology. Visn. Nats. Akad. Nauk Ukrainy No. 1, 40 (2001) (in Ukrainian).

7. M.V. Strikha. The centennial of semiconductor science: Origins and Ukrainian contribution. Ukr. J. Phys. 59, 831 (2014).

8. V.G. Lytovchenko. Academician of the NAS of Ukraine Vadym Evgenovych Lashkaryov: The outstanding physicist of the 20th century, the discoverer of $p-n$-junction (to the 55th anniversary of the foundation of the Institute of Semiconductor Physics of the NAS of Ukraine). Ukr. J. Phys. 61, 181 (2016).

9. V.E. Lashkaryov. Investigations of a barrier layer by the thermoprobe method. Ukr. J. Phys. 53, Spec. Issue, 53 (2008).

10. M. Avenarius. On Thermoelectricity (St. Petersburg, 1864) (in Russian).

11. M. Avenarius. On Electrical Differences of Metals at Various Temperatures (St. Petersburg, 1866) (in Russian).

12. M. Avenarius. On the electroexcitation force of thermoelectric elements from the viewpoint of the mechanical theory of heat. Univers. Izv. No. 11, 1 (1870) (in Russian).

13. O. Khvolson. Course of Physics. Vol. 3. Heat Theory (Gos. Izd., 1923) (in Russian).

14. A.G. Goldman. Mikhail Petrovich Avenarius and Kiev school of experimental physics. Usp. Fiz. Nauk 44, 586 (1951) (in Russian).

15. A.A. Rudnitskii. Thermoelectric Properties of the Noble Metals and Their Alloys (U.S. Atomic energy commission, 1959).

16. F.N. Shvedov. On the Significance of Non-Conductors in Electrostatics (Tipogr. Yakobson., 1868) (in Russian).

17. F.N. Shvedov. On the Conversion Laws of Electricity into Heat (Odessa, 1870) (in Russian).

18. Professors of Odessa (Novorossiysk) University. Biographical Dictionary. Vol. 1. Rectors (Astroprint, 2005) (in Ukrainian).

19. F.N. Shvedov. What Is Hail? (Demakov, 1881) (in Russian).

20. F.N. Shvedov. Methodology of Physics. Introduction (Tsentr. Tiporg., 1894) (in Russian).

21. M.M. Matiiko, S.I. Inozemtsev. Contribution of Domestic Scientists to the Electricity Science (Radyans'ka Shkola, 1952) (in Ukrainian).

22. K.K. Khrenov. Underwater Electric Welding and Cutting of Metals (Voenn. Izdat., 1946) (in Russian).

23. E.O. Paton. High-Speed Automatic Welding Under a Flux Layer (Mash. Gos. Izdat., 1941) (in Russian).

24. P.G. Borzyak. Photoelectric phenomena in photovoltaic elements at low temperatures. Visti Akad. Nauk UkrSSR 3, 19 (1936) (in Ukrainian).

25. M. Pylchikov. Materials to the Issue of Local Anomalies in Terrestrial Magnetism. Master's thesis (1888) (in Russian).
26. M. Piltschikoff. Sur la phase initiale d'électrolyse. Compt. Rend. 108, 614 (1889).

27. M. Piltschikoff. Sur la polarisation électrolytique par les métaux. Compt. Rend. 108, 898 (1889).

28. F.D. Miroshnichenko. On the history of the development of the magnetism theory in Ukraine. In Materials of the All-Union Scientific Conference on the History of Physical and Mathematical Sciences (Tambov, 1971), p. 135 (in Russian).

29. D.A. Rozhanskii. Electric Rays: The Theory of Electromagnetic Oscillations and Waves (Izd. K.L. Rikker, St.Petersburg, 1913) (in Russian).

30. D.S. Shteinberg. On the Magnetization and Coercive Force of Ferromagnetic Powders (Physical Laboratory of Imperial Kharkiv University, 1915) (in Russian).

31. D.S. Shteinberg, V.S. Surkov. Coercive force of microscopic magnetite spills. Uchen. Zap. Kharkiv. Univ. 2-3, 95 (1935) (in Ukrainian).

32. D.S. Shteinberg. Dalblom Pocket Magnetometer (Physical Laboratory of Kharkiv University, 1916) (in Russian).

33. L.W. Schubnikow, W.J. de Haas. Neue Erscheinungen bei der Widerstandsänderung von Wismuthkristallen im Magnetfeld bei der Temperatur von flüssigem Wasserstoff. Leiden Comm. Kamerlingh Onnes Lab. nos. 207, 207a, 210a, 210b (1930).

34. L.W. Schubnikow, W.J. de Haas. Neue Erscheinungen bei der widerstandsänderung von wismuthkristallen im magnetfeld bei der temperatur von flüssigem wasserstoff. Proc. Amst. Acad. Sci. 33, 418 (1930).

35. N.B. Brandt, S.M. Chudinov. Shubnikov-de Haas effect and its application to investigation of the energy spectrum of metals, semimetals, and semiconductors. Sov. Phys. Usp. 25, 518 (1982).

36. O.I. Balabekyan. L.V. Shubnikov. Usp. Fiz. Nauk 89, 321 (1966) (in Russian).

37. A.A. Abrikosov. Type II superconductors and the vortex lattice. Usp. Fiz. Nauk 174, 1234 (2004) (in Russian).

38. L.D. Landau. A possible explanation of the field dependence of the susceptibility at low temperatures. Phys. Z. Sow. 4, 675 (1933).

39. E.M. Lifshits. Lev Davidovich Landau. Usp. Fiz. Nauk 97, 169 (1969) (in Russian).

40. L.D. Landau, E.M. Lifshitz. On the theory of the dispersion of magnetic permeability in ferromagnetic bodies. Phys. Z . Sow. 8, 153 (1935).

41. V.B. Yuferov. Evgenii Stanislavovich Borovik. The second cryogenic laboratory of the UPTI. Vopr. At. Nauki Tekhn. 6, 65 (2004) (in Russian)).

42. E.S. Borovik. Electrical conductivity of metals at high current density. Dokl. Akad. Nauk SSSR 91, 771 (1953) (in Russian).

43. E.S. Borovik, A.S. Milner. Lectures on Ferromagnetism (Kharkiv State University, 1960) (in Russian).

44. E.S. Borovik, V.V. Eremenko, A.S. Milner. Lectures on Magnetism (Fizmatlit, 2005) (in Russian).

45. G.G. Kordun. Soviet Physicists (Vyshcha Shkola, Kyiv, 1975) (in Ukrainian). 
46. B.N. Rzhonsnytskyi. F.A. Pirotskyi. The Inventor of the Tram (Derzhtekhvydav Ukrainy, 1951) (in Ukrainian).

47. I.L. Polyakova, E.A. Popova-Kyandskaya. Nikolai Dmitrievich Pilchikov. Usp. Fiz. Nauk 53, 121 (1954) (in Russian).

48. A.A. Slutskin, D.S. Shteinberg. Obtaining oscillations in cathode tubes with the aid of a magnetic field. $Z h$. Russ. Fiz. Khim. Obshch. Ser. Fiz. 58, 395 (1926) (in Russian).

49. G.G. Kordun. On the development of radiophysics and electronics in Ukraine. In Materials of the 1st Ukrainian Interuniversity Conference on the History of Physics (Simferopol, 1968) (in Russian).

50. Utility patent No. 5592, CLASS 21a1, 32. June 30, 1928, Leningrad "Description of an apparatus for electric telescopy to the patent of V.I. Popov, B.P. Grabovskii, and N.G. Piskunov from November 9, 1925 (application certificate No. 4899)" (in Russian).

Received 15.07.19.

Translated from Ukrainian by O.I. Voitenko
I.В. Корсун

ВНЕСОК УКРАЇНСЬКИХ

НАУКОВЦІВ У РОЗВИТОК ЕЛЕКТРОДИНАМІКИ

$\mathrm{P}$ е $з$ ю м е

Метою статті є довести важливість робіт українських науковців для розвитку електродинаміки. Фізичні теорії електропровідності, доменної структури феромагнетиків, фотоелектрорушійної сили у напівпровідниках, мікроскопічна теорія надпровідності, ефект Шубнікова-де Гааза, магнітоакустичний резонанс, винахід електротрамваю, трансляція рухомого зображення у прямому ефірі, радіокерування об'єктами на відстані, дугове електрозварювання металів приклади досягнень українських вчених в області електродинаміки. Більшість українських науковців створили власні наукові школи, роботи яких є визнаними у світі. Вчені займалися не лише науковою і викладацькою діяльністю, але й популяризацією науки, реформуванням системи освіти, громадською роботою. 